\title{
MENGAPA PENGGUNA NARKOBA PADA REMAJA AKHIR RELAPSE?
}

\author{
Evi Afifah Hurriyati \\ Jurusan Psikologi, Fakultas Psikologi, Bina Nusantara University, \\ Jln. Kemanggisan Ilir III No.45, Kemanggisan, Jakarta Barat 11480 \\ e_afifah@binus.ac.id
}

\begin{abstract}
This research is to acknowledge causes why drug users in late adolescent, who had followed drug recovery program in drug rehabilitation centre, are relapsing at the time they came back to subject environment. This research's background is supported with the increasing numbers of drug addictive users in Indonesia, especially in adolescent. The result of this research showed an uncondusive situation, such as conflict with parents (father) when they got back to house environment, causes they are coping maladaptive, i.e. relapse. Conflict with father causes adolescent has negative perception towards social support from the father, and it effects their religious orientation and locus of control. For future research, it is suggested to do quantitative research so it can be gained measurable result statistically.
\end{abstract}

Keywords: relapse, coping stress, conflict with father, late adolescent

\begin{abstract}
ABSTRAK
Penelitian ini bertujuan mengetahui faktor penyebab mengapa pengguna narkoba pada remaja akhir, yang sudah mendapatkan program penyembuhan narkoba di lembaga rehabilitasi narkoba, mengalami relapse (kekambuhan) pada saat kembali ke lingkungan subjek. Penelitian ini dilatarbelakangi oleh kenyataan penderita ketergantungan narkoba di Indonesia mengalami peningkatan, khususnya pada remaja. Hasil penelitian menunjukkan pada situasi yang tidak kondusif, seperti adanya konflik dengan orangtua (ayah) ketika mereka kembali ke lingkungan rumah, menyebabkan mereka melakukan coping maladaptif yaitu relapse. Konflik dengan ayah menyebabkan remaja mempunyai persepsi yang negatif terhadap adanya dukungan sosial dari ayah, mempengaruhi orientasi religiusitas dan locus of control remaja. Untuk penelitian selanjutnya disarankan agar melakukan penelitian dengan pendekatan kuantitatif sehingga diperoleh hasil yang dapat terukur secara statistik.
\end{abstract}

Kata kunci: relapse, coping stres, konflik dengan ayah, remaja akhir 


\section{PENDAHULUAN}

Di Indonesia, perkembangan pencandu narkoba semakin pesat. Berdasarkan data dari Badan Narkotika Jawa Barat (2010), para pencandu narkoba itu pada umumnya berusia antara 11 sampai 24 tahun. Mengapa pada tahap usia perkembangan individu, remaja yang paling banyak melakukan penyalahgunaan narkoba? Menurut hasil survey yang dilakukan Sprinthall \& Collins (1995), beberapa masalah psikologi pada remaja meliputi depresi, gangguan makan, dan penyalahgunaan narkoba. Thorne \& DeBlassic dalam Rice (1996), mereka menyatakan bahwa penyalahgunaan narkoba dianggap sebagai suatu masalah kesehatan sosial yang paling banyak dikaitkan dengan remaja. Jika dilihat dari tahap perkembangannya, remaja merupakan masa transisi dari masa kanak-kanak menuju masa dewasa.

Hall dalam Rice (1996) mendeskripsikan remaja sebagai suatu periode pada tahap transisi, penuh dengan storm and stress. Menurut Hall, masa pubertas adalah periode usia penuh masalah, benturan-benturan dalam penyesuaian diri yang emosional, dan ketidakstabilan, suatu masa dimana mood remaja berubah secara ekstrem antara suka dan tidak suka, ceria-depresi, berani-malu. Ada beberapa faktor yang mempengaruhi remaja melakukan penyalahgunaan narkoba. Menurut O'Doherty \& Davies dalam Fisher \& Reason (1988), faktor-faktor tersebut adalah adanya keinginan mencari aktivitas yang memberikan kenyamanan, variabel sosiodemografi, pengaruh keluarga, dan kelompok teman sebaya yang secara ekstrim merupakan faktor yang menentukan apakah seseorang akan menggunakan narkoba atau tidak.

Menurut konsep model perilaku ketergantungan adiksi dari Brickman (dalam Rozenweig \& Porter, 1988) pengguna narkoba atau aktivitas ketergantungan dimotivasi oleh usaha individu untuk beradaptasi terhadap stress yang agaknya lebih dihubungkan dengan akibat penggunaan narkoba itu sendiri dibandingkan dengan awal ketergantungan narkoba (Alexander \& Hadaway, 1982; Peele, 1985; Pohorecky \& Brixk, 1983, dalam Rozenweig \& Porter, 1988). Perubahan diri pada pengguna narkoba tidak terjadi secara spontan. Hasil penelitian ditemukan bahwa ada sejumlah faktor yang mempengaruhi individu yang mengalami ketergantungan narkoba, yang menunjukkan bahwa mereka melakukan penyesuaian (adjustment). Penyesuaian diri tersebut dilakukan karena adanya tuntutan yang dapat bersifat internal maupun eksternal (Lazarus, 1984). Dengan kata lain mereka melakukan coping.

Menurut Lazarus, coping stress merupakan usaha aktif yang dilakukan seseorang untuk mengatasi masalah yang dihadapinya, serta bagaimana orang itu secepatnya menyesuaikan diri dengan tuntutan, baik yang berasal dari luar ataupun dari dalam dirinya. Dengan kata lain, coping merupakan gambaran dari petjuangan atau usaha seseorang, sebagai usaha terbaik yang dapat dilakukan dalam menghadapi situasi yang sulit dalam kehidupan (Pargament, 1997). Remaja juga berbeda dalam mengembangkan strategi copingnya. Ada yang memfokuskan pada masalah (problem-focused strategies) atau pada emosi yang mereka alami ketika menghadapi masalah (emotion-focused strategies). Kebanyakan remaja menggunakan strategi coping yang beragam (Compas, 1987; Ebata, 1991; dalam Sprinthall \& Collins, 1995).

Namun, ketika remaja tidak mampu mengembangkan kemampuan strategi coping stress-nya, mereka bisa relapse. Adapun relapse (kekambuhan) didefinisikan sebagai penyalahgunaan narkoba kembali setelah beberapa lama berhenti menyalahgunakan narkoba. Relaspse merupakan karakteristik alamiah penderita ketergantungan narkoba (Talbott \& Martin dalam Sari, 2003). Dalam penelitian ini penulis dipilih subjek remaja, karena dari sudut perkembangannya remaja berada pada tahap transisis, yang merupakan masa yang rentan terhadap stress. Lebih spesifik lagi, penelitian ini membatasi pada remaja pengguna narkoba, yang diasumsikan memiliki tingkat stress yang cukup tinggi dan secara kesehatan mental bermasalah. 
Penelitian ini bertujuan untuk mengetahui faktor penyebab mengapa pengguna narkoba pada remaja akhir yang sudah mendapatkan program penyembuhan narkoba di pesantren rehabilitasi narkoba mengalami relapse (kekambuhan) pada saat kembali ke lingkungan subjek. Dalam hal ini adalah remaja akhir yang mengalami ketergantungan narkoba pada fase perubahan aktif (tahap komitmen untuk berubah) dan sedang dirawat di pesantren rehabilitasi.

\section{METODE PENELITIAN}

Dalam penelitian ini digunakkan metode pendekatan kualitatif dengan studi kasus, dikarenakan untuk memperoleh pemahaman yang menyeluruh dan utuh tentang fenomena yang akan diteliti, serta ingin memberikan perhatian pada kedalaman dan penghayatan subyek terhadap masalah yang akan diteliti. Selain itu dideskripsikan proses dinamis yang terjadi berkenaan dengan gejala yang diteliti. Studi kasus memfokuskan pada fenomena kontemporer di dalam konteks kehidupan nyata (Yin, 1989). Dalam penelitian ini digunakan metode pengambilan data dengan teknik kuesioner, observasi dan wawancara. Adapun kuesioner untuk melihat aspek jenis pola coping stress, orientasi religiusitas ( suatu keadaan di mana individu mengakui adanya kekuatan tertinggi yang menaungi kehidupan manusia, dan hanya kepada-Nya manusia bergantung serta berserah diri, [Dister, 1982]) locus of control, dan persepsi terhadap dukungan sosial yang diterimanya yang hasilnya berupa data skor nilai skala digunakan sebagai alat bantu dalam menggali dan menginterpretasikan hasil wawancara. Dari data dan hasil wawancara nantinya dapat diinterpretasikan mengapa subjek dalam penelitian ini relapse.

Adapun karakteristik subjek penelitian adalah: remaja berusia pada tahap remaja akhir (usia 17-21 tahun), mengalami ketergantungan narkoba dan sedang mengikuti program penyembuhan di rumah rehabilitasi, berada di pesantren rehabilitasi untuk mengikuti program penyembuhan minimal sudah 3 bulan (dengan asumsi dalam jangka waktu 3 bulan diharapkan subjek sudah dapat beradaptasi dengan kondisi pesantren). Metode penyembuhan yang dilakukan di pesantren rehabilitasi dengan menggunakan pendekatan religi. Penelitian ini membatasi sampel penelitian pada subjek remaja akhir, yang memenuhi criteria karakteristik yang sesuai dengan tujuan penelitian seperti yang telah disebut di atas. Hal ini dilakukan agar sampel sungguh-sungguh mewakili terhadap fenomena yang diteliti. Adapun jumlah sampel tidak diarahkan pada jumlah yang besar, melainkan pada kasus-kasus tipikal sesuai kekhususan masalah penelitian. Dalam penelitian ini penulis membatasi pada dua subjek, yang mewakili kriteria di atas. Yaitu subjek 1 (21 tahun) dan subjek 2 (18 tahun).

Pengambilan data dilakukan sebanyak tiga kali kali, yaitu tahap pertama pada saat mereka sudah berda selama kurang lebih 3 bulan di pesantren rehabilitasi, tahap kedua 3 bulan berikutnya dan tahap ketiga 6 bulan berikutnya pada saat kedua subjek kembali ke pesantren rehabilitasi setelah kembali dari lingkungan keluarga. Untuk tahap kedua subjek 1 tidak bisa diwawancarai karena sedang kembali ke keluarganya.

\section{HASIL DAN PEMBAHASAN}

Dari hasil penelitian diperoleh data sumber stres (stressor) dan aspek internal personal subjek kedua subjek dari tahap pertama sampai tahap ketiga masa penyembuhan di tempat rehabilitasi dapat dilihat pada Tabel 1 di bawah ini: 
Tabel 1 Data Sumber Stres (Stressor) dan Aspek Internal Personal Kedua Subjek

\begin{tabular}{|c|c|c|c|c|c|c|}
\hline Aspek & \multicolumn{3}{|l|}{ Subjek 1} & \multicolumn{3}{|l|}{ Subjek 2} \\
\hline Sumber Stress & Tidak ada & - & $\begin{array}{l}\text { Konflik dengan } \\
\text { Ayah }\end{array}$ & Tidak ada & $\begin{array}{l}\text { Kelulusan } \\
\text { dan Konflik } \\
\text { dengan Ayah }\end{array}$ & $\begin{array}{l}\text { Konflik dengan } \\
\text { Ayah }\end{array}$ \\
\hline Pola Coping Stress & $\begin{array}{l}\text { Emotion } \\
\text { Focused } \\
\text { Strategies, } \\
\text { Adaptif }\end{array}$ & - & $\begin{array}{l}\text { Problem Focused } \\
\text { Strategies, } \\
\text { Maladaptif }\end{array}$ & $\begin{array}{l}\text { Problem } \\
\text { Focused } \\
\text { Strategies, } \\
\text { Adaptif }\end{array}$ & $\begin{array}{l}\text { Emotion } \\
\text { Focused } \\
\text { Strategies }\end{array}$ & $\begin{array}{l}\text { Emotion \& } \\
\text { Problem Focused } \\
\text { Strategies, } \\
\text { Maladaptif }\end{array}$ \\
\hline Orientasi Religiusitas & Intrinsik & - & Intrinsik & Ekstrinsik & Ekstrinsik & Intrinsik \\
\hline Locus of Control & Internal & - & Internal & Internal & Internal & Internal \\
\hline $\begin{array}{l}\text { Persepsi Terhadap } \\
\text { Dukungan Sosial }\end{array}$ & Positif & - & $\begin{array}{l}\text { Positif } \text { (teman, } \\
\text { mentor) Negatif } \\
\text { (Ayah) }\end{array}$ & Positif & Positif & $\begin{array}{l}\text { Positif (teman, } \\
\text { mentor) Negatif } \\
\text { (Ayah) }\end{array}$ \\
\hline
\end{tabular}

Remaja pengguna narkoba pada kasus ini mempunyai sumber stres yang mereka persepsikan berbeda pada setiap tahapnya selama masa penyembuhan. Pada tahap 3 bulan pertama kedua subjek tidak menafsirkan adanya sumber stres. Sehingga pada tahap ini mereka cukup adaptif. Pada tahap selanjutnya yaitu tahap kedua dan ketiga, mereka mulai menafsirkan adanya sumber stres. Pada tahap kedua, subjek 2 menafsirkan kelulusan dan konflik dengan ayah sebagai sumber stres. Kelulusan dianggapnya sebagai tekanan karena ia khawatir tidak lulus. Kekhawatiran ini disebabkan karena subjek 2 sudah dua kali tidak naik kelas. Keinginan subjek 2 untuk melanjutkan kuliah dan memilih jurusan Psikologi ditentang ayahnya yang menginginkan subjek 2 tidak melanjutkan kuliah dulu, menjadi konflik yang berlanjut pada tahap ketiga.

Konflik dengan ayah terjadi pada subjek 1 . Keinginan subjek 1 untuk kembali melanjutkan kuliah dengan jurusan yang berbeda ditentang ayahnya yang menginginkan subjek 1 masuk militer seperti dirinya yang purnawirawan ABRI. Selain itu subjek 1 tampaknya mempunyai konflik dengan ayahnya tentang masalah lain, yang tidak ingin diungkapkannya lebih lanjut. Menurutnya masalah tersebut berasal dari ayah subjek 1 yang tidak menampilkan figur ayah yang baik bagi dirinya. Kedua subjek mengatasi masalah yang ditafsirkan sebagai kondisi yang menekan dengan strategi coping yang berbeda pada setiap tahapnya. Pada tahap pertama subjek 1 lebih cenderung mengembangkan pola coping stress emotion focused strategies, sedangkan subjek 2 lebih cenderung problem focused strategies. Pada tahap kedua subjek 2 lebih banyak mengembangkan strategi coping stress emotion focused strategies. Pada tahap ketiga subjek 1 lebih banyak menggunakan problem focused strategies sedangkan subjek 2 mengembangkan kedua strategi coping tersebut.

Biasanya mereka menggunakan coping problem focused dengan cara mencari informasi untuk menyelesaikan masalahnya melalui teman sesama pengguna, kakak, mentor ataupun pimpinan pesantren. Sedangkan strategi coping emotion focused strategies dilakukan dengan cara mencari bimbingan kepada mentor, pimpinan pesantren atau kakak. Mereka juga biasanya mencari hiburan untuk sejenak menghilangkan masalahnya dengan cara pergi ke mall atau nonton TV. Dengan demikian dapat disimpulkan bahwa setiap subjek tidak hanya menggunakan satu pola coping stress, tetapi juga dapat mengembangkan kedua pola jenis coping stress, yaitu problem focused strategies atau emotional focused strategies.

Kedua subjek remaja pada kasus ini mempunyai orientasi religiusitas yang berbeda. Subjek 1 mempunyai orientasi religiusitas yangcenderung intrinsik pada tahap pertama dan tahap ketiga. Sedangkan subjek 2 mempunyai orientasi religiusitas yang cenderung ekstinsik pada dua tahap penyembuhan. Sementara itu pada tahap setelah relapse mempunyai orientasi yang cenderung intrinsik. Kedua subjek mengakui bahwa religiusitas dipersepsikan sebagai hal yang mempengaruhi pemulihan mereka sebaga remaja pengguna narkoba untuk tidak menggunakan narkoba lagi. Tetapi kenyataannya,kedua subjek pada kasus ini mengalami relapse. Kondisi seperti ini sesuai dengan hasil 
penelitian dari McIntosh et al, 1993, yang menyatakan bahwa respondennya sering menyatakan keyakinan dan praktek agama membantu coping stress, tetapi pada kenyataannya tidak menunjukkan hubungan antara agama dan adjustment. Dapat pula dikatakan bahwa hal itu tidak menunjukkan bagaimana agama dapat membantu dalam adjustment. Kedua subjek mempunyai locus of control yang cenderung internal dan hal tersebut berlaku pada setiap tahap bersifat stabil. Walaupun nilai skor menunjukkan adanya perubahan pada setiap skor sub skala, baik pada nilai internal, powerful other maupun chance.

Faktor situasi dan kondisi, seperti konflik dengan ayah cukup mempengaruhi perubahan aspek locus of control. Locus of control mereka yang cenderung internal berpengaruh pada keyakinan bahwa mereka dapat mengendalikan diri ketika menggunakan narkoba lagi (relapse). Pengalaman keduanya dalam mengkonsumsi narkoba, menyebabkan mereka merasa mamu mengontrol penggunaan narkoba. Mereka menganggap bahwa mereka sendirilah yang dapat mengendalikan penggunaan narkoba dengan cara mengatur penggunaannya.

Pada setiap tahap, baik pada tahap penyembuhan maupun setelah relapse kedua subjek tetap mempersepsikan adanya dukungan sosial. Dukungan ini yang mereka terima berupa bimbingan, penghargaan dan sebagainya mereka terima dari anggota keluarga, seperti ibu, kakak, juga dari teman sesama pengguna maupun dari mentor dan pemilik pesantren. Adapun kualitas tipe dukungan sosial yang diterima dari orang-orang tersebut dipersepsikan subjek berbeda pada setiap tahap. Misalnya subjek 2 mempersepsikan dengan baik untuk tipe penghargaan pada dua tahap sebelum relapse, namun kemudian dipersepsikan kurang baik pada saat setelah relapse.

Untuk tahap ketiga kedua subjek mengalami relapse. Keduanya tidak mampu bertahan untuk tidak menggunakan narkoba. Relapse merupakan karakterisik alamiah pada penderita ketergantugan narkoba. Para penyalahgna narkoba seringkali mencoba berhenti menyalahgunakan narkoba tersebut, sebelum akhirnya mereka bergabung dalam panti rehabilitasi, tetapi kenyataannya sulit untuk menghentikan terhadap obat terlarang (Talbott \& Martin dalam Sari, 2003).

Kasus kedua subjek sejalan dengan suatu penelitian yang menunjukkan bahwa $90 \%$ penyalahguna narkoba mengalami relapse dalam setahun masa pengobatannya (Thomb dalam sari, 2003). Konflik dengan orang tua terutama ayah menjadi salah satu penyebab memicu mereka untuk kembali menggunakan narkoba. Adanya konflik dengan ayah membuat mereka stres. Hal ini seperti yang diungkapkan kedua subjek:

"Keinginan papa tidak sejalan dengan jiwa saya... Percuma ngomong dengan papa, dari keempat anak papa tidak ada menyatu dengan papa“" (Subjek 1)

"Pas saya ingin maju selalu ada pemikiran ortu yang lain, beda pendapat. Papa orang yang paling keras di sini, keinginannya harus dipenuhi” (Subjek 2)

Terjadi penurunan religiusitas pada Subjek 1 dibandingkan dengan tahap pertama. Sebaliknya terjadi peningkatan tingkat religiusitas dibandingkan dengan tahap sebelumnya. Hal ini diduga penurunan religiusitas pada disebabkan karena lingkungan di rumah tidak kondusif. Faktor keluarga yang mempengaruhi kepercayaan religiusitas dan praktek religious remaja adalah pola asuh orang tua. Orang tua yang authoritarian (kurang memberikan motivasi dan dorongan untuk berprestasi namun melakukan kontrol yang ketat) akan menciptakan anak yang mengadopsi nilai-nilai yang tidak sama dengan orang tuanya (Rice, 1996). Penulis menduga ayah subjek 1 yang mempunyai latar belakang militer menerapkan pola asuh authoritarian, sehingga subjek 1 tidak mengadopsi nilai-nilai yang tidak sama dengan orang tuanya. Relasi dalam keluarga juga akn menciptakan iklim sejuk yang akan mempermudah atau menghalangi remaja mengadopsi nila-nilai orang tuanya.

Sedangkan pada subjek 2 terjadi peningkatan nilai religiusitas pada tahap ketiga. Penulis menduga peningkatan nilai religiusitas pada subjek 2 disebabkan karena subjek 2 berada di lingungan keluarga yang cukup kondusif untuk menjalan ibadah. Subjek 2 mengakui bahwa ketika ia berada di 
rumah sering melakukan sholat berjamaan dan ayahnya bertindak sebagai imam. Bagi remaja muslim, seringnya keluarga melaksanakan sholat berjamaah baik di rumah maupun di mesjig, mengadakan diskusi kajian agama Islam tentunya sangat berpengaruh terhadap pembentukan kepercayaan religius Islam. Terutama bagi anak laki-laki peranan ayah sebagai tokoh model dalam melakukan praktek keagamaan sangat penting sebab akan menjadikan anak laki-laki mengidentifikasikan diri dengan ayahnya (Clark, Worthington \& Danser dalam Rice, 1996).

Namun demikian locus of control keduanya masih memiliki kecendrungan internal. Pengalaman keduanya dalam mengkonsumsi narkoba, menyebabkan mereka merasa mamou mengontrol penggunaan narkoba. Mereka menganggap bahwa mereka sendirilah yang dapat mengendalikan penggunaan narkoba dengan cara mengatur penggunaannya. Seperti yang dikatakan keduanya:

"Istilahnya permainan cantik. Saya bisa mengontrol penggunaannya, kapan pakai kapan tidak" (Subjek 1)

Misalnya seninnya saya pake, besoknya saya nganter mama ke pengajian atau shopping” (Subjek 2)

Dengan demikian locus of control mereka yang cenderung internal lebih kepada keyakinan bahwa mereka dapat mengontrol penggunaan narkoba karena pengalamannya. Keduanya masih mempersepsikan adanya dukungan sosial, namun demikian ada beberapa penurunan skor untuk tipe dukungan social tertentu. Misalnya Subjek 2 mengakui penurunan dalam mempersepsikan tipe penghargaan dibandingkan dengan tahap-tahap sebelumnya.

Terjadi perubahan pola coping stress pada kedua subjek yang sebelumnya memiliki pola problem focused strategies berubah menjadi emotion focused strategies. Sedangkan subjek 2 pada tahao pertama mempunyai pola problem focused strategies, tahap kedua berubah menjadi emotion focused strategies dan tahap kedua mengembangkan pola yang seimbang antara problem focused maupun emotion focused strategies.

Terlihat adanya dinamika pola coping stress dan orientasi religiusitas subjek dari setiap tahap, pada kedua subjek. Hanya saja dinamika pola coping stress dan orientasi subjek 1 hanya bisa diamati dua tahap. Setiap subjek tidak hanya menggunakan satu pola perilaku coping stress, tetapi dapat mengembangkan kedua pola jenis coping stress, yaitu poblem focused dan emotion focused strategies. Hal tersebut sesuai dengan hasil penelitian Compas \& Ebata dalam Sprinthall \& Collins (1995) bahwa kebanyakan remaja menggunakan strategi coping yang beragam. Adapun dilihat dari tugas perkembangannya sebagai seorang remaja akhir, adalah keinginan dan harapan dari ketiga subjek untuk melanjutkan kuliah dan mempersiapkan untuk memilih karir.

\footnotetext{
"Saya nanti kuliah, papa yang jadi sponsor, dia yang mendanai. Kalo kondisi di rumah masih seperti itu, saya kost aja" (Subjek 1)

"Ke depannya saya tidak mau tinggal di rumah, tidak mau konflik dengan ortu, saya pengen mandiri, mungkin tinggal di rumah saudara saya atau pesantren lagi dengan cara kuliah” (Subjek 2)
}

Namun demikian, keinginan dan harapan mereka, untuk melanjutkan pendidikan tidak sepenuhnya mendapat dukungan dari orangtua, dalam hal ini adalah ayah. Hal ini disebaban karena adanya perbedaaan pendapat antara ayah dan anak dalam masalah penentuan arah masa depan. Perbedaan pendapat tersebut bisa saja disebabkan karena kekurangpercayaan orang tua terhadap anaknya yang seringkali menyalahgunakan kepercayaan orang tua. Subjek 2 misalnya sudah dua kali mengalami relapse, setelah keluar dari pesantren. Hal inilah yang menyebabkan ayahnya menghendaki agar subjek 2 tidak melanjutkan kuliah dulu.

Sementara subjek 1 berbeda pendapat dengan ayahnya dalam masalah penentuan minat. Dalam bidang pendidikan, subjek 1 lebih berminta untuk memilih bidang yang bersifat entertain. Sementara ayahnya menginginkan subjek 1 mengikuti jejaknya untuk memilih bidang kemiliteran. 
Konflik orang tua-anak akan mempengaruhi perkembangan religious remaja. Orang tua yang autoritarian (kurang memberikan motivasi dan dorongan untuk berprestasi namun melakukan kontrol yang ketat) akan menciptakan anak yang mengadopsi nilai-nilai yang tidak sama dengan orang tuanya (Rice, 1990).

Demikian juga orang tua yang cenderung memahami tingkat kemampuan yang dimiliki anak dan tetap menekankan pada anak untuk berusaha sebaik mungkin sesuaai dengan kemampuan yang dimiliki akan mencapai hasil optimal yang mungkin dicapainya. Jadi akan tertanam pada diri anak bahwa usaha yang dilakukannya akan mempengaruhi dan menentukan hasil yang diperoleh.

Kondisi ini tidak terjadi pada orang tua kedua subjek Bahkan, ayah subjek 2 justru tidak mempercayainya lagi untuk beraktifitas diluar pesantren untuk melanjutkan kuliah. Penulis beranggapan bahwa hal tersebut dalam mempengrauhi dinamika locus of control subjek 2 yang pada setiap tahap berubah, bahkan pada tahap ketiga mempunyai locus of control yang cendenderung internal tetapi skor eksternal powerful other cukup tinggi.

\section{Konflik Interpersonal Ayah-Remaja Laki-laki}

Dari hasil penelitian diperoleh kesimpulan bahwa subjek remaja pengguna narkoba pada kasus ini dalam setiap masa perubahan aktif mempunyai pola coping stress maupun orientasi religiusitasnya dengan dinamika tertentu. Pada tahap penyembuhan selama 6 bulan di pesantren kedua subjek remaja pada kasus ini cukup adaptif dan terlihat cukup religius. Kondisi ini sejalan dengan penelitian yang menunjukkan bahwa pengguna narkoba yang berada pada tahap pemulihan (recovery) cenderung untuk menempatkan pentingnya sembahyang,percaya pada Tuhan dan perasaan keyakinan yang kuat terhadap agamanya.

Penelitian yang dilakukan Pardini \& Plante (2002) menemukan bahwa keyakinan religious dan spiritual dihubungkan dengan hasil kesehatan mental dan fisik yang positif. Pardini \& Plante menyatakan bahwa keyakinan agama dan spiritual yang lebih tinggi mempunyai hubungan yang cukup signifikan dengan pola coping yang adaptif, lebih tabah menghadapi stres, tingkat orientasi hidup yang optimis, tingkat persepsi terhadap dukungan sosial yang lebih besar dan tingkat kcemasan yang lebih rendah. Dari penelitian yang dilakukan diperoleh hasil bahwa kedua subjek dalam kasus ini mengalami relapse pada tahap mempertahankan perubahan aktif. Dengan demikian, kasus dalam penelitian ini kurang sejalan dengan penelitian yang dilakukan Pardini \& plante di atas.

Hal yang perlu untuk didiskusikan pada kasus ini adalah penyebab dari kedua subjek yang tidak mampu mempertahankan perubahan aktif agar tidak memnggunakan narkoba (relapse). Pada kasus ini relapse terjadi ketika mereka kembali ke lingkungan rumah dan lingkungan teman sesama pengguna narkoba.Kedua subjek remaja pada kasus ini mengakui bahwa konflik mereka dengan ayahnya menjadi salah satu faktor pemicu yang menyebabkan mereka kembali menggunakan narkoba. Faktor lain adalah tersedianya uang dan kesempatan untuk bertemu kembali dengan teman sesama pengguna serta faktor internal subjek sendiri.

Subjek pada penelitian ini berada pada tahap perkembang remaja akhir. Menurut penelitian yang dilakukan Larson \& Ham (1993) menunjukkan bahwa rata-rata afek negatif lebih banyak terjadi pada remaja yang lebih tua dibandingkan usia yang lebih muda. Subjek remaja pada penelitian ini diasumsikan sebagai remaja normal dengan tugas perkembangan sebagai remaja akhir. Konflik subjek remaja-ayah pada kasus ini berkaitan dengan tugas perkembangan remaja akhir seperti minat yang ditentang dalam menentukan jurusan di peruguan tinggi, dan kurangnya kepercayaan ayah terhadap anaknya dikarenakan riwayat anak sebagai pengguna narkoba. Narlatt \& Gordon dalan Rosenzweig \& Poerter (1998) mengemukakan model perilaku proses relapse yang mengasumsikan bahwa resiko untuk relapse ditentukan oleh interaksi factor individu, situasi dan fisiologis. Situasi rumah yang 
dipersepsikan penuh konflik oleh kedua subjek pada kasus ini menjadi faktor yang mempengaruhi mengapa mereka relapse.

Hubungan ayah-anak yang tidak harmonis sangat berpengaruh terhadap perkembangan remaja, yang dapat berdampak pada perkembangan religiusitasnya. Terutama bagi anak laki-laki dimana peranan ayah sebagai tokoh model sangat penting dalam melakukan praktek keagamaan, sebab anaklaki-laki mengidentifikasikan diri dengan ayahnya (Clark, Worthington \& Danser dalam Rice, 1990). Relasi dala keluarga juga akan menciptakan iklim sejuk yang dapat mempermudah atau menghalangi remaj mengadopsi nila-nilai orang tuanya. Konflik keluarga terutama konflik ayah-anak akan menghalangi transmisi religious kepada remaja (Cook \& Bengtoon dalam Rice, 1990). Kedua remaja pada kasus ini cukup religious, walaupun mempunyai orientasi religiusitas yang berbeda. Subjek 1 cenderung berorientasi intrinsik, sedangkan subjek 2 cenderung ekstrinsik. Namun demikian, keduanya sama-sama tidak mampu untuk mempertahankan diri untuk tidak menggunakan narkoba lagi (relapse).

Diasumsikan bahwa meskipun kedua subjek pada kasus ini cukup religius, namun keduanya kurang menginternalisasikan nilai-nilai dan aturan agama secara mendalam di kehidupannya. Sehingga ketika mereka kembali ke lingkungan di luar pesantren, tidak mampu menjadikan nilai-nilai agama yang diperolehnya menjadi suatu kontrolinternal ketika menghadapi stress. Sebab, menurut Clark dalam Hastuti (1998),diketahui bahwa nilai-nilai dan aturan harus diinternalisasi.Internalisasi tersebut memberikan perubahan dalam karakter struktur kualitatif dan perasaan bermoral sebagai hasil seseorang mengikuti aturan-aturan yang sangat sulit.

Pendidikan agama sejak dini akan memperkuat komitmen agama. Melalui pendidikan sejak dini tersebut anak-anak belajar menginternalisasi nilai-nilai yang ada di lingkungannya menjadi system kepercayaan dan akan diampakkan dalam perilakunya sehari-hari. Religiusitas masa remaaj merupakan konsolidasi religious masa kanak-kanak untuk kemudian dikonfrontasikan dengan kenyataan yang dihadapi. Akibatnya remaja menjadi mampu untuk berperilaku religious dan kreatif (Clark dalam Hastuti, 1998).

Kedua subjek dalam kasus ini mendapatkan pendidikan agama sejak dini, bahkan sampai tingkat sekolah menengah atas, mereka sekolah di institusi bernuansa agama (Islam). Mereka juga mendapatkan treatment keagamaan di rumah rehabilitasi ketika berada dalam tahap penyembuhan. Walaupun kedua subjek pada kasus ini selalu mengatakan bahwa treatment keagamaan yang diberikan institusi rumah rehabilitasi membantu mereka untuk sembuh atau tidak menggunakan narkoba lagi, namun kenyataannya setelah mereka kembali ke lingkungan di luar institusi rehabilitasi mereka relapse. Diduga adanya konflik ayah-anak remaja laki-laki menyebabkan kurangnya konsolidasi religiusitas masa kanak-kanak ketika masa remaja. Sebab, dalam kaitannya dengan religiusitas, pada kasus ini orang tua jarang atau tidak pernah membicarakan konsep dan prinsip religious terutama yang berhubungan dengan masalah penerapan hokum agama dalam perbuatan seperti konsep halal dan haram. Hal tersebuy penting karena praktek religious sangat dipengaruhi oleh frekuensi diskusi tentang agama di rumah (Clark, Worthington \& Danset dalam Rice, 1996).

Akibatnya kedua subjek remaja pada kasus ini tidak berperilaku religius ketika menghadapi kenyataan hidup yang dipersepsikannya sangat menekan. Bahkan, kedua subjek dalam kasus ini selalu menghindar untuk bertemu dengan ayahnya ketika mereka berada di rumah. Sehingga tidak ada komunikasi yang baik antara ayah dan anak. Bagi remaja muslim, seringnya keluarga melaksanakan sholat berjamaah baik di rumah maupun di masjid, mengadakan diskusi kajian agama Islam tentunya sangat berpengaruh terhadap pembentukan kepercayaan religius Islam. Terutama bagi anak laki-laki peranan ayah sebagai tokoh model dalam melakukan praktek keagamaan sangat penting sebab akanmenjadikan anak laki-laki mengidentifikasikan diri dengan ayahnya. 
Locus of control merupakan faktor internal subjek yang cukup mempengaruhi perilaku coping stress seseorang. Locus of control merupakan konsep yang menggambarkan keyakinan seseorang mengenai sumber penentu perilakunya (Rotter dalam Lina dan Rosyid, 1997). Pada kasus ini, kedua remaja mempunyai tingkat locus of control yang cenderung internal dengan tingkat orientasi hidup yang optimis. Karakteristik orang dengan locus of control internal ialah mempunyai keyakinan bahwa individu sendirilah yang bertanggungjawab atas kesuksesan atau kegagalan yang dialaminya. Karakter seperti itu tampak pada kedua subjek remaja pada kasus dalampenelitian ini, ketika mereka membuat keputusan untuk relapse. Mereka mengakui, bahwa keputusannya untuk relapse karena keinginan sendiri. Locus of control mereka yang cenderung internal lebih kepada keyakinan bahwa mereka dapat mengontrol penggunaan narkoba karena pengalaman relapse-nya terdahulu.

Faktor sosial ekonomi juga mempengaruhi locus of control individu (London \& Exner, dalam Hapsari, 1996). Status sosial ekonomi sangat mempengaruhi perilaku seseorang, dan bagaimana individu berekasi atau melakukan penyesuaian dengan lingkungannya juga sangat dipengaruhi oleh locus of controlnya. Rotter dalam Lina dan Rosyid (1997) menyatakan bahwa perilaku seseorangfintentukan oleh interaksi antara harapan, nila-nilai yang ada pada seseorang serta lingkungan dimana ia berada. Harapan-harapan ini dapat menentukan kontrol seseorang apakah sebagai penguat pada kontrol internal atau eksternal. Hal ini sejalan dengan penelitian Marlatt \& Gordon dalam Fisfer \& Reason (1998) pada perilaku relapse.

\section{Efficacy Expectancies dan Outcomes Expectancies pada Perilaku Proses Relapse}

Marlatt \& Gordon dalam Fisher (1998), mengemukakan model mengenai perilaku proses relapse. Mereka mengasumsikan bahwa resiko relapses ditentukan oleh interaksi antara individu, situasi dan fisiologis. Berkaitan dengan internal individu dalam hal relapse, ada dua bentuk expectancy (pengharapan) yaitu efficacy expectancies dan outcome expectancies yang mempunyai peranan penting. Efficacy expectancies merupakan komponen penting dalam sejumlah teori penggunaan narkoba dan relapse (Marlatt \& Gordon dalam Fisfer \& Reason, 1998).

Teori-teori tersebut menyatakan bahwa individu sepertinya lebih banyak menggunakan narkoba ketika mereka merasa tidak sanggup atau tidak mempunyai kompetensi untuk melakukan coping stress atau pada keadaan mood yang negative. Outcome expectancies menggambarkan keyakinan individu bahwa alcohol atau narkoba dapat mengahasilkan akibat yang diinginkan, misalnya dengan memberikan efek positif atau memungkinkannya menghindari,meminimalkan atau keluar dari emosi atau kondisi negative (Adeso; Crichlow, Donovan \& Marlatt; Goldman, Lang \& Michalec; Oei \& Jones dalam Fisher \& Reason, 1998).

Pada kasus penelitian ini kedua subjek berada pada status social ekonomi menengah ke atas,dimana mereka dapat memperoleh uang dengan mudah untuk membeli narkoba. Mereka kembali menggunakan narkoba (relapse) ketika tidak sanggup atau tidak mempunyai kompetensi untuk melakukan coping stress pada situasi yang dipersepsikannya sebagai konflik. Kurangnya kompetensi untuk melakukan coping stress tersebut karena kedua subjek pada kasus ini kurang menginternalisasikan nilai-nilai dan aturan agama yang diperolehnya sejak kecil, bahkan ketika berada pada tahap penyembuhan di institusi rehabilitasi dengan pendekatan agama. Selain itu kedua subjek pada kasus ini berada pada tahap fisiologis ketergantungan. Ketergantungan secara psikologis disebut juga sebagai habituasi yang ditandai dengan adanya kecanduan zat yang kontinu atau intermitten dalam usaha untuk menghindari keadaan disforia (Davidson \& Neale dalam Amita, 2001). Pada kondisi seperti itu kedua subjek mempunyai outcome expectancies bahwa narkoba dapat menghasilkan efek yang diinginkan, seperti perasaan euforia atau merasa keluar dari kondisi yang negatif. 


\section{Dukungan Keluarga}

Selain karakter individu dapat mempengaruhi respon coping, dukungan social yang merupakan sumber daya yang penting dalam mempengaruhi coping individu. Secara normal dukungan social ada melalui kelompok komunitas yang meliputi keluarga,lingkungan teman, dan limgkungan kerja. Dalam beberapa hasil penelitian diketahui bahwa dukungan social berperan dalam proses penyembuhan seorang penderita ketergantungan. Selain itu ada beberapa karakteristik yang dimilki oleh penderita ketergantungan,seperti rentan terhadap stress, memiliki harga diri yang rendah, rendahnya control diri dan ketidakyakinan akan hasil yang akan dicapai membuat dukungan social mempunyai peran untuk mengatasinya (Amita, 2001).

Penelitian mengenai dukungan keluarga terhadap remaja yang menggunakan narkoba, ditemukan bahwa dukungan orang tua konsisten berkaitan dengan akibat yang positif, sedangkan dukungan kelompok peer sering tidak berhubungan dengan akibat yang positif (Hoelter \& Harper; Larson, Steinberg, Dornbuch \& Brown dalam Hetheringthon \& Blechman, 1996).

Kedua subjek pada kasus ini tidak mempersepsikan ayah sebagai oarng yang memberikan dukungan. Bahkan keduanya mempersepsikan ayah sebagai sumber konflik. Sehingga konflik dengan ayah menjadi salah satu factor yang memicu mereka untuk relapse. Dengan kata lain, konflik remaja pengguna narkoba dengan ayahnya pada kasus ini, berkaitan dengan akibat negative. Jika dikaitkan dengan tahap perkembangannya, maka remaja mulai melepas ketergantungannya pada orang tua, Mereka akan berorientasi pada kelompon remaja (peer). Apalagi kedua remaja pada kasus ini tidak meneumukan kenyamanan dalam keluarga seperti yang mereka butuhkan. Padahal keluarga dengan komunikasi efektif dapat memungkinkan remaja melakukan coping dengan tepat bahkan dalam menghadapi tantangan yang dapat mengganggu perkembangannya sekalipun.

Dalam masalah inilah, peer sangat berpengaruh. Bagi remaja, meningkatnya perkembangan sosial berlanjut kepada perubahan keseimbangan oreintasi individu anatara keluarga dan keompok teman sebaya (peer group). Ini artinya, ada tanggung jawab personal yang dihubungkan dengan jaringan sosial yang lebih luas, dengan berkurangnya sejumlah waktu luang bersama keluarga di rumah. Dengan demikian, pengalaman social remaja lebih banyak,luas dan secara kualitatif berbeda daripada masa anak-anak. Dengan meningkatnya autonomi personal, secara potensial menyebablan meningkatnya resiko mengalami peristiwa-peristiwa yang mungkin tidak diperbaiki oleh factor keluarga yang sebelumnya dipandang sebagai pelindung dalam menghadapi peristiwa-peristiwa yang menekan (stressful) dan sulit. Ada sebuah pergeseran yang menekankan pada identifikasi teman sebaya (peer) dan penggunaan coping personal yang lebih besar darpada perlindungan keluarga (Goodyear, 1998 dalam Fisher \& Reason, 1998). Padahal penelitian yang dilakukan oleh Hoelter \& Helper dalam Hetherington \& Blechman (1996) mengenai dukungan kelkuarga terhadap remaja yang menggunakan narkoba, ditemukan bahwa dukungan orang tua secara konsisten berkaitan dengan dampak positif, sedangkan dukungan kelompok peer sering tidak berhubungan dengan dampak positif.

\section{SIMPULAN}

Berdasarkan hasil dan pembahasan, dapat disimpulkan mengapa pengguna narkoba pada remaja akhir yang berada pada tahap penyembuhan (tahap perubahan aktif) mengalami relapse. Kedua subjek pada kasus ini memiliki dinamika dalam mempersepsikan dan mengatasi stres dengan aspekaspek yang mempengaruhinya. Aspek-aspek tersebut adalah aspek internal subjek seperti orientasi religiusitas, locus of control dan persepsi terhadap adanya dukungan sosial yang diterima, maupun aspek eksternal subjek seperti lingkungan (keluarga, teman) dan treatment. Kedua subjek mengalami relapse pada tahap ketiga penyembuhan setelah kembali ke lingkungan keluarga. Adanya situasi 
konflik ayah dan remaja laki-laki ini mempengaruhi aspek-aspek internal kedua subjek (religiusitas, locus of control dan persepsi terhadap adanya dukungan social). Kedua subjek dalam kasus ini cukup religius, namun adanya konflik ayah-anak remaja laki-laki menyebabkan kurangnya konsolidasi religiusitas masa kanak-kanak ketika masa remaja. Kedua subjek kurang menginternalisasi nilai-nilai agama, sehingga ketika ada keduanya mempersepsikan adalnya sumber stress mereka kurang memiliki kompetensi untuk melakukan coping stress. Kondisi ini membuat mereka rentan untuk mengalami relapse ketika menghadapi situasi yang dianggap menekan.

Locus of control mereka yang cenderung internal pada kedua subjek lebih kepada keyakinan bahwa mereka dapat mengontrol penggunaan narkoba karena pengalaman relapsenya terdahulu. Keduanya mempersepsikan tidak adanya dukungan social dari ayah bahkan konflik dengan ayah terkait tugas perkembangan remaja akhir yaitu dalam melanjutkan pendidikan dan penentuan minat menjadi sumber stress. Saran praktis dari penelitian ini adalah orang tua hendaknya mengembangkan pola asuh yang bersifat autoritatif, perlu adanya penanaman dan internalisasi nilai-nilai religiusitas sejak dini, baik di rumah, sekolah dan masyrakat dan adanya kurikulum sekolah tentang life skill ke arah kualitas kehidupan yang lebih baik pada remaja. Sedangkan untuk saran penelitian selanjutnya adalah agar melakukan penelitian dengan jumlah subjek yang lebih banyak dengan melihat pengaruh perbedaan faktor treatment, usia, tingkat ketergantungan dan pola asuh orangtua. Untuk penelitian selanjutnya disarankan agar melakukan penelitian dengan pendekatan kuantitatif sehingga diperoleh hasil yang dapat terukur secara statistik

\section{DAFTAR PUSTAKA}

Amitha, R. (2001). Dukungan Sosial yang Diperlukan PadaMasa Penyembuhan Remaja Penderita Ketergantungan Heroin. Skripsi. Jakarta: Program S1 Universitas Indonesia.

Dister, N. S. (1982). Pengalaman dan Motivasi Beragama: Pengantar Psikologi Agama. Jakarta: Lembaga Penunjang Pembangunan Nasional (Leppmas).

Fisher, S., \& Reason. (1988). Handbook of Life Stress, Cognition \& Health. USA: John Willey \& Sons.

Hetherington, E. M., \& Blechman, E. A. (1996). Stress, coping and resiliency in Children and Families. New Jersey, USA, Lawrence Erlbaum.

Hastuti, K. (1998). Hubungan Religiusitas Regulasi Diri dan Aktivitas Seksual Dalam Berpacaran pada Remaja Kristen. Tesis. Jakarta, Progam S2 Universitas Indonesia.

Larson, R \& Ham, L. (1993). Stress and "Storm and Stress" in Early Adolescence; The Relationship of Negative Events with Dysphoric Affect. Journal Developmentl Psychology, Volume 29 Novenmber 1 P 130-140

Lazarus, R., \& Folkman, S. (1984). Stress, Appraisal and Coping. New York: Springe Publishing.

Lina \& Rosyid, H.F. (1997) Perilaku Konsumtif Berdasarkan Locus of Control Pada Remaja Putri. Jurnal Pemikiran dan Penelitian Psikologi. No 4, Tahun XI, 5-13

Pardini \& Plante. (2002). Religiousity \& Mental Health. http://www.APA (Agustus, 2002) 
Pargament, K.I. (1997). The Psychology of Religion and Coping. New York, USA: The Guilford Press.

Rice, F.P. (1996). The Adolescence Development, Relationships and Culture. Boston; Allyn \& Balcon.

Rosenzweig, M. R. \& L.W. Porter. (1988). Annual Review of Psychology. Vol. 39 California, USA. Annual Reviews Inc

Sari, A.D. (2003). Perbedaan Profil EPPS (Edwards Personal Preference Schedule) pada Penyalahguna dan Bukan penyelahguna Narkoba. Thesis, Jakarta: Program S2 Universitas Indonesia.

Sprinthall, N., \& W. A. Collins. (1995). Adolescent Psychology, A Developmental View. (3rd ed.). New York: McGraw-Hill, Inc.

Yin, R. K. (1980). Case Study Research. Applied Social Research Method Series. Vol.5. USA: SAGE Publication. 